\title{
STRATIFICATION CONDITIONS DETERMINING SEED DORMANCY RELEASE OF EUROPEAN BLADDER NUT (STAPHYLEA PINNATA L.)
}

\author{
TADEUSZ TYLKOWSKI \\ Laboratory of Seed Biology \\ Institute of Dendrology, Polish Academy of Sciences \\ Parkowa 5, 62-035 Kórnik, Poland \\ e-mail: ttylkows@rose.man.poznan.pl
}

(Received: May 29, 2006. Accepted: September 12, 2006)

\begin{abstract}
European bladder nut has its northern limit in Poland and is legally protected. Climatic conditions, edible seeds attractive for small animals and seed dormancy to a large extent affect its restocking under natural conditions. The aim of this study was to determine conditions for seed dormancy release.

Nuts dried after collection to ca $11 \%$ of moisture content (fresh weight basis) may be stored without loss of seed viability for over 1 year in a cold store at the temperature of $-3^{\circ} \mathrm{C}$. For the purpose of seed dormancy release nuts need to be stratified. Seed dormancy release was found highest after the application of warm-followed-bycold stratification, first for 4-6 weeks at the temperature of $15^{\circ} \mathrm{C}$ or at cyclically alternating temperature of $10 \sim 20^{\circ} \mathrm{C}(24+24 \mathrm{~h} / \mathrm{cycle})$, followed by $16-18$ weeks at $3^{\circ} \mathrm{C}$. Seeds germinate at $3^{\circ} \mathrm{C}$ with the same rate as at cyclically alternating temperature of $3 \sim 15^{\circ} \mathrm{C}(16+8 \mathrm{~h} /$ day $)$. Drying of nuts at room temperature to approx. $11 \%$ during the warm stratification phase (after 2 or 4 weeks) and further stratification resulted in a significant increase in seed germinability. In some seed lots scarification of nuts (dried during the warm stratification phase) contributes to a further significant increase of seed germinability.
\end{abstract}

KEY WORDS: scarification; germination, sowing pretreatment.

\section{INTRODUCTION}

European bladder nut (Staphylea pinnata L.) is a shrub of medium height, up to 5-6 (9) m high, yielding numerous root suckers. In Poland this species is found rather rarely and is covered by strict legal protection. Bladder nut is a thermophyte and most frequently occupies stands of southern exposure at the slope foot. Its geographical limit in Poland reaches its northern limit, south of $52^{\circ}$ parallel. Under natural conditions it is found primarily in forests and coppices, on limestone sites which do not dry during the vegetation season, located in Silesia, on the WielunCzęstochowa Upland and more frequently in the Carpathian Foothills (Gostyńska 1961). Archeobotanical studies in Poland indicate a much broader range of bladder nut in the Tertiary period (Środoń 1992). Staphylea pinnata avoids lowlands. It occurs in upland areas in river valleys of central and southern Europe, from southern France (The Vosges and Lorraine), to the Balkans in Bulgaria and Krasnodar on the Black Sea.

The first element of the Polish common name [kłokoczka południowa] refers to the characteristic rattle heard in autumn when the wind shakes twigs burdened with ripe fruits. The fruit of bladder nut is a leathery, inflated round capsule (with 2-3 cases), with 1-4 (7) relatively large, approx. $1 \mathrm{~cm}$ in diameter, hard, spherical nuts with a light brown and shiny coat. In English, bladder nut is named due to the appearance of the inflated capsule resembling the bladder. Seeds contained in the capsule may also resemble hard pistachio seeds, thus in French bladder nut is called „false pistachio” (faux pistachier). Fragrant bladder nut flowers are white or pinkish, collected in abundant clusters, blooming in May or June. They may be autogamous or entomophilous.

Oil pressed from nuts was used for lighting in former times. Moreover, bells, rattles and rosaries were made from seeds with an attractive shiny coat. In the past bladder nut was cultivated in relation with magic properties ascribed to it and used in religious rites and culture rituals (Cieciński 2004). To satisfy aesthetic and cultural needs plants were most frequently dug out and transferred from forests to be planted in the vicinity of houses and temples. For this reason some archeologists are of the opinion that in places where bladder nut is growing, remnants of former settlements may be expected to be found (Latałowa 1994).

The considerable weight of bladder nut seeds (Beranová and Benediková 2005) prevents its spread over farther distances. After falling to the ground they are willingly eaten 
by small animals. Only scarcely seeds grow into seedlings in the vicinity of maternal plants. Seeds may be disseminated by squirrels (Browicz 1959). The introduction of bladder nut to large scale cultivation is prevented by the lack of insight into methods of seed dormancy release, both in Poland and other countries where this plant is found.

The rare occurrence and scarce generative progeny of bladder nut within its geographical limits were the reasons why studies were undertaken to develop procedures of seed handling to produce seedlings. In order to actively protect an endangered species it is necessary to know first the conditions of its propagation. It does not refer here to vegetative propagation, connected with cloning and reduction of gene pool. Ex situ protection in arboreta and botanical gardens is only a partial solution to this problem. In available literature there is very limited information on generative propagation of bladder nut.

These scarce and frequently divergent pieces of information contributed to our decision to undertake studies on the determination of optimum conditions of seed storage, dormancy release and germination of bladder nut.

\section{MATERIAL AND METHODS}

Several experiments were conducted in 2000-2004 at the Laboratory of Seed Biology of the Institute of Dendrology PAS in Kórnik on seed dormancy release and germination in bladder nut. Four of these experiments are presented in this study. Seeds for tests were collected at the permission of the Minister of the Environment (permit no. BOA-A$135-2330 / 01 / \mathrm{RP}$ ) at the beginning of October 2000 and 2001 from several shrubs in the Dukla forest district and in 2001 in the Arboretum in Bolestraszyce.

Moisture content (MC) of nuts as a percentage of water (fresh weight basis) was determined after their crushing and drying at the temperature of $105^{\circ} \mathrm{C}$ for $24 \mathrm{~h}$.

Results of laboratory seed germination were transformed to $\operatorname{arc} \sin \sqrt{ } \%$ and subjected to the MANOVA variance analysis using the Statistica (1997) programme and tested with the use of the Tukey test at the confidence level of $\mathrm{P}=0.05$.

\begin{tabular}{|c|c|c|}
\hline $15 \sim 25^{\circ} \mathrm{C}$ & & $3 \sim 20^{\circ} \mathrm{C}$ \\
\hline 8 weeks & $3^{\circ} \mathrm{C}$ & \\
\hline
\end{tabular}

Germinability (\%)

\begin{tabular}{|c|c|c|}
\hline $15 \sim 25^{\circ} \mathrm{C}$ & & $3 \sim 20^{\circ} \mathrm{C}$ \\
\hline 12 weeks & $3^{\circ} \mathrm{C}$ & \\
\hline
\end{tabular}

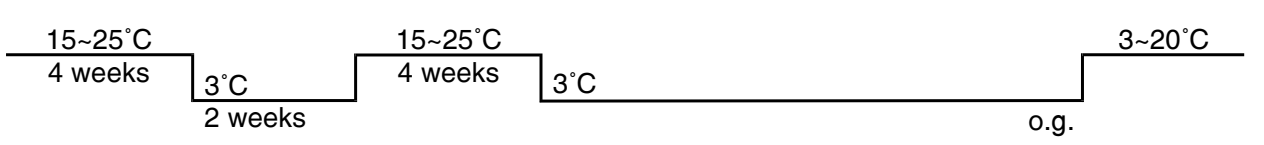

$\begin{array}{cc}\text { C } & \text { CB } \\ 10.7 \mathrm{~h} & 30.0 \mathrm{abc}\end{array}$

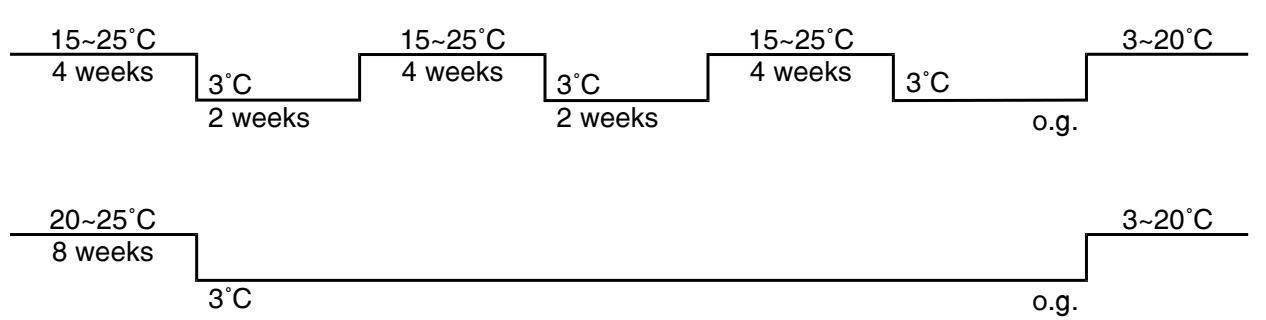

E $15.3 \mathrm{fgh}$

EB $28.0 \mathrm{abcd}$
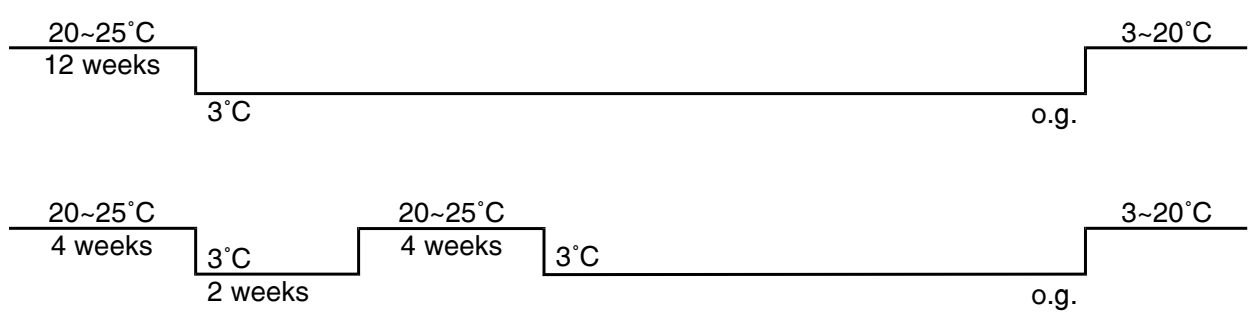

o.g.
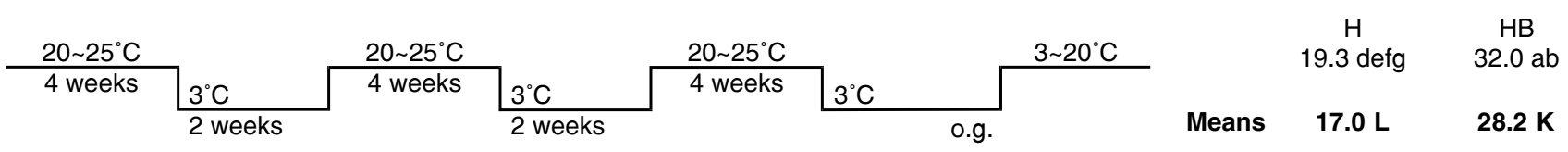

FB

24.7 bcde $\quad 34.7 \mathrm{ab}$

G $\quad G B$ 17.3 efgh $\quad 36.0 \mathrm{a}$

Fig. 1. Seed germinability corresponding to stratification thermal layout of Experiment 1. Symbols: A-H - seeds not dried after collection; AB-HB - seeds dried after collection; o.g. - onset of seed germination. Results were tested using Tukey's T-test. Identical letters denote values which do not differ significantly at $\mathrm{P}=0.05$. 


\section{Experiment 1}

Non-dried nuts after being collected in 2000 (Dukla Forest District), with the MC of $32.2 \%$ and nuts dried at room temperature to $11.3 \%$ were stratified in a substrate. As a substrate a $1: 1(\mathrm{v} / \mathrm{v})$ moist mixture of glass-sand with sieved peat with $\mathrm{pH}$ of 6.5 was used. Optimum substrate moisture content was tested manually by squeezing in the hand - a single drop of water should leak between fingers (Gordon and Rowe 1982, Suszka at all 1996). Nuts, in 3 replications of 50 nuts each, were mixed with the substrate $(1: 3 \mathrm{v} / \mathrm{v})$ and stratified in a warm-followed-by-cold or warm-cold-warm-cold systems, according to the design presented in Figure 1.

During the warm phase of stratification cyclically alternating temperature was applied (under controlled conditions): $15 \sim 25^{\circ} \mathrm{C}$ or $20 \sim 25^{\circ} \mathrm{C}$ in two-day cycles, i.e. $24 \mathrm{~h}$ at lower temperature and next $24 \mathrm{~h}$ at higher temperature per cycle. In the warm-followed-by-cold phase the warm phase lasted 8 or 12 weeks, while in the warm-cold-warm-cold system 4-week warm phases were interrupted by a 2-week cold phase at $3^{\circ} \mathrm{C}$. In both thermal systems after the last warm phase there was a long-term (20-24 weeks) cold phase at $3^{\circ} \mathrm{C}$, i.e. until the onset of seed germination.

Once a week during the warm phase and every two weeks in the cold phase stratified nuts/seeds were removed from $250 \mathrm{ml}$ containers, aired and possible moisture losses were eliminated in the substrate, after which they were again placed in containers. To prevent excessive evaporation containers were covered with perforated lids.

After the completion of the cold stratification phase, defined by the appearance of the first germinating seeds, seeds were subjected to a germination test at cyclically variable temperature at $3 \sim 20^{\circ} \mathrm{C}\left(16 \mathrm{~h}\right.$ at $3^{\circ} \mathrm{C}$ and $8 \mathrm{~h}$ at $20^{\circ} \mathrm{C}$ every day) in identical substrate as during stratification. Seeds were considered germinated when the radicle was over $5 \mathrm{~mm}$ long.

\section{Experiment 2}

Nuts from several shrubs were collected in October 2001 in the Dukla Forest District. Empty nuts were isolated after separation in alcohol and removed. Full nuts with MC of $14.3 \%$ were stored in tightly closed containers from 17 October 2001 to 3 December 2002 at the temperature of $-3^{\circ} \mathrm{C}$. After storage nuts (in 3 replications 50 nuts each) were used in the experiment (Fig. 2), the aim of which was to compare the effect on seed germination of the drying procedure (for 3 days at room temperature) and drying and mechanical scarification after the completion of the warm phase of warm-followed-by-cold stratification at $15 \sim 25^{\circ} / 3^{\circ} \mathrm{C}$ in the substrate. The applied stratification substrate was identical as in the previous experiment. The warm phase of stratification in the cycle $(24+24 \mathrm{~h}$ /cycle) lasted for 2,4 and 6 weeks. The effect of the germination test temperature at constant temperature of $3^{\circ} \mathrm{C}$ and cyclically variable temperature of $3 \sim 15^{\circ} \mathrm{C}$ (in the cycle of $16+8 \mathrm{~h} /$ day) on seed germinability was also compared.

Mechanical scarification of dried nuts was performed manually. Nuts with the stigma directed upwards held in two fingers (thumb and index finger) were placed between vice jaws and were carefully crashed over the largest circumference until a characteristic cracking sound of the breaking coat was heard.

\section{Experiment 3}

After collection in the Dukla Forest District in 2000 nuts dried to $\mathrm{MC}$ of $11.3 \%$ were stored for 14 months in a tightly closed container at the temperature of $-3^{\circ} \mathrm{C}$. After storage moisture content of nuts decreased to $10.7 \%$. Nuts were subjected to warm-followed-by-cold stratification in the substrate (as in experiment 1), in 3 replications with 50 seeds each (Fig. 3). The warm phase of stratification for 0,2 , 4 and 6 weeks was conducted at a constant temperature of

Germinability (\%)

\begin{tabular}{|c|c|c|}
\hline $15 \sim 25^{\circ} \mathrm{C}$ & & $3 \sim 15^{\circ} \mathrm{C}$ \\
\hline & $3^{\circ} \mathrm{C}$ & $3^{\circ} \mathrm{C}$ \\
\hline $\begin{array}{l}B-4 \text { weeks } \\
C-2 \text { weeks }\end{array}$ & & \\
\hline
\end{tabular}

A

$18.0 \mathrm{~d}-\mathrm{f}$ $22.0 \mathrm{~b}-\mathrm{f}$ 16.7 ef $22.7 \mathrm{~b}-\mathrm{f}$ $12.0 \mathrm{f}$ 20.7 c-f
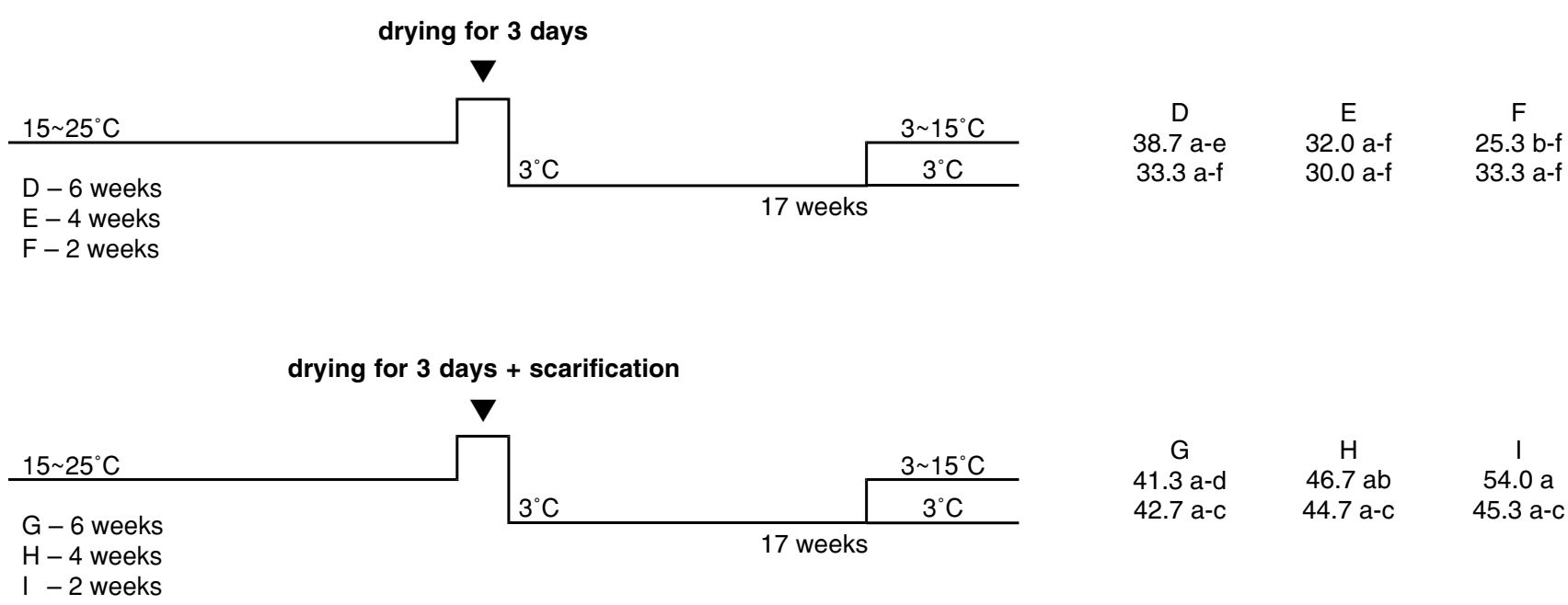

Fig. 2. Seed germinability corresponding to scheme of warm-followed-by-cold stratification of Experiment 2 . Symbol $\boldsymbol{\nabla}-$ drying of nuts for 3 days at room temperature. Results were tested using Tukey's T-test. Identical letters used to denote values which do not differ significantly at $\mathrm{P}=0.05$. 


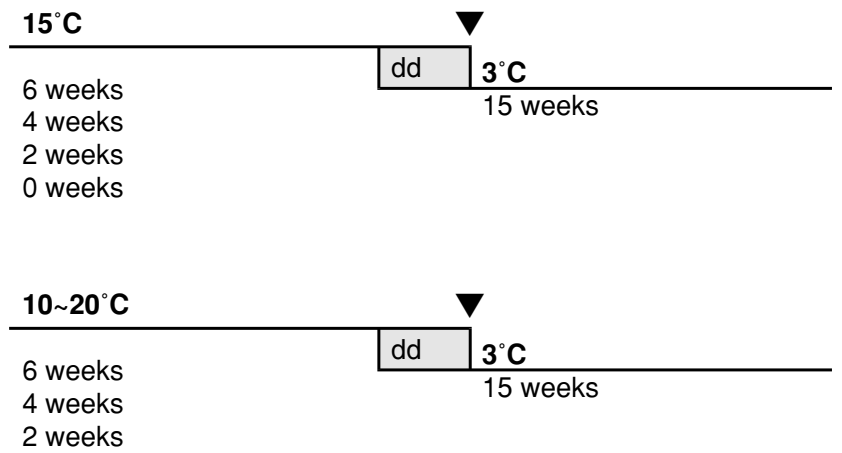

Fig. 3. Scheme of warm-followed-by-cold $15^{\circ} / 3^{\circ} \mathrm{C}$ or $10 \sim 20^{\circ} / 3^{\circ} \mathrm{C}$ stratification of Experiment 3. Symbols: dd - drying of nuts for 5 days; $\boldsymbol{\nabla}$ - mechanical scarification of nuts.

$15^{\circ} \mathrm{C}$ or at cyclically alternating temperature of $10 \sim 20^{\circ} \mathrm{C}$ (changed every $24 \mathrm{~h}$ ). After the warm phase nuts were dried for 5 days at room temperature until MC of approx. $11 \%$, followed by mechanical scarification as in Experiment 2. After scarification nuts were stratified in the substrate at the temperature of $3^{\circ} \mathrm{C}$, until the completion of seed germination.

\section{Experiment 4}

Nuts, collected from several shrubs in 2001 in the Arboretum in Bolestraszyce, were sent by mail to the Institute of Dendrology on 17 December 2001. After determination of moisture content $(10.7 \%)$ they were packed to containers and stored at $-3^{\circ} \mathrm{C}$ until 14 April 2003. After storage the experiment was conducted according to the design presented in Figure 4.

Nuts were stratified in the substrate in 4 replications with 40 nuts, each in the thermal system of $15^{\circ} / 3^{\circ} \mathrm{C}$, with the warm phase of 9 weeks. During this phase nuts were dried for 2 days at room temperature, once after 6 weeks (variants $\mathrm{A}$ and $\mathrm{B}$ ) or twice (after 4 and 6 weeks - variants $\mathrm{C}$ and D) or three times (after 2, 4 and 6 weeks - variants $\mathrm{E}$ and $\mathrm{F}$ ). Additionally after the last drying nuts were scarified mechanically in a vice (variants $\mathrm{B}, \mathrm{D}$ and F).

\section{RESULTS}

\section{Experiment 1}

The weight of 1000 fresh nuts (with MC of 32.2\%) was approx. $275 \mathrm{~g}$.

Irrespective of the applied thermal system during the warm phase of stratification, the first germinating seeds appeared in the cold phase of stratification at $3^{\circ} \mathrm{C}$ after $20-27$ weeks (fresh seeds 4-10\%, dried seeds 4-20\%). Elevation of the germination test temperature from $3{ }^{\circ} \mathrm{C}$ to $3 \sim 20^{\circ} \mathrm{C}$ resulted in a relatively small increase in seed germinability. After 4 weeks at $3 \sim 20^{\circ} \mathrm{C}$ germination settled at the level of

\begin{tabular}{|c|c|c|c|c|}
\hline $\begin{array}{l}\mathrm{A} \\
15^{\circ} \mathrm{C}\end{array}$ & & & & Germinability [\%] \\
\hline 6 weeks & 3 weeks & $3^{\circ} \mathrm{C}$ & $3^{\circ} \mathrm{C}$ & $70.3 \mathrm{ab}$ \\
\hline
\end{tabular}
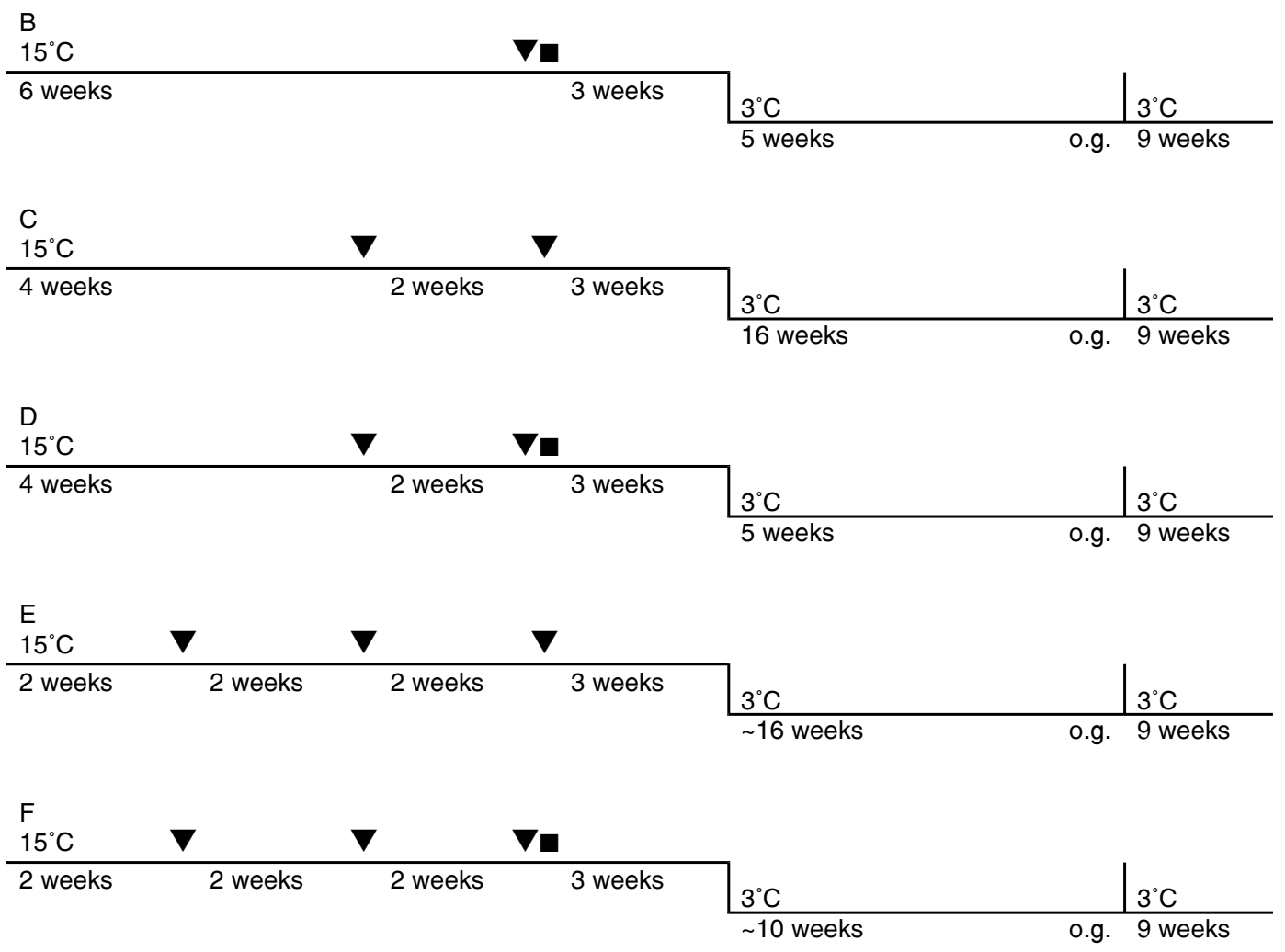

Fig. 4. Seed germinability corresponding to scheme of stratification layout of Experiment 4. Symbols: $\mathbf{\nabla}$ - drying of nuts at room temperature for 2 days; - mechanical scarification of nuts; o. g - onset of germination. Results were tested using Tukey's T-test. Identical letters denote values which do not differ significantly at $\mathrm{P}=0.05$. 
$10.7-24.7 \%$ for fresh seeds and $11.3-36.0 \%$ for seeds dried after collection (Fig. 1).

The highest germination rate was found for seeds dried after collection to the moisture content of $11.3 \%$ and next stratified in the thermal system of $20 \sim 25^{\circ} / 3^{\circ} / 20 \sim 25^{\circ} / 3^{\circ} \mathrm{C}$ for $4+2+4+23$ weeks, respectively. A total of only $17.3 \%$ seeds, which were not dried after collection, germinated in the identical thermal layout system.

After the completion of the germination test most seeds, which did not germinate and did not show signs of decay, had light-colored coats (in contrast to several decayed seeds with dark colored coats). In an experiment, which is not described in this study, most healthy seeds germinated after repeated stratification.

It results from the analysis of variance that all the analyzed factors had a statistically significant effect on seed germinability. The application of cyclically variable temperature of $20 \sim 25^{\circ} \mathrm{C}$ during the warm phase of stratification resulted in a higher seed germinability than that at the temperature of $15 \sim 20^{\circ} \mathrm{C}$ (Fig. 5). Also the thermal layout with an 8 -week warm phase (variant $\mathrm{A}-$ Figs 1 and 6) resulted in

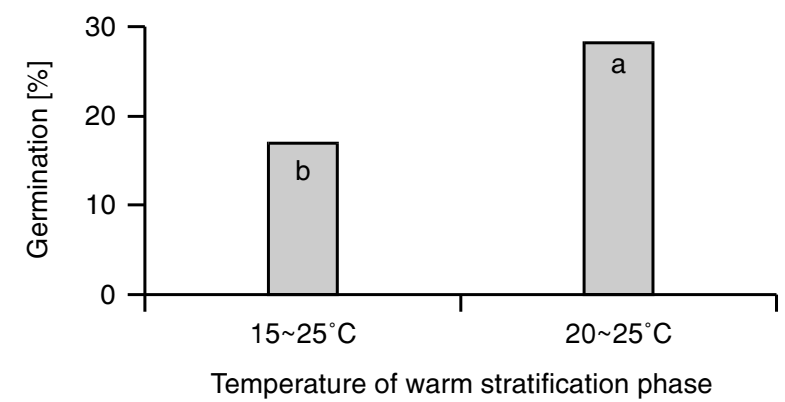

Fig. 5. The effect of warm phase temperature on seed germinability. Results denoted with identical letters do not differ significantly at $\mathrm{P}=0.05$ (Tukey's T-test).

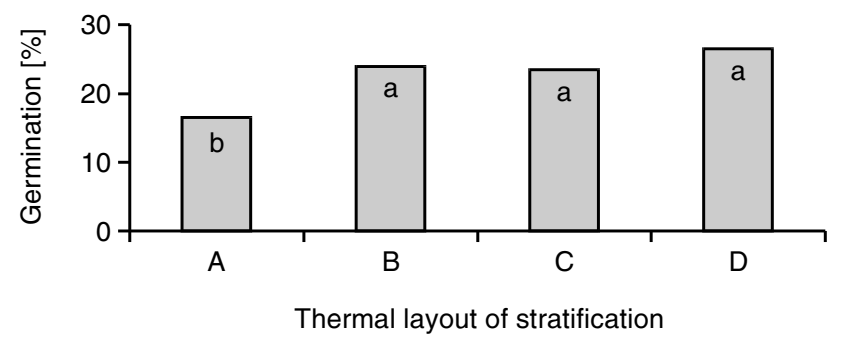

Fig. 6. The effect of stratification thermal layout (A, B, C and D - denotations as in Figure 1) on seed germination. Results denoted with identical letters do not differ significantly at $\mathrm{P}=0.05$ (Tukey's T-test).

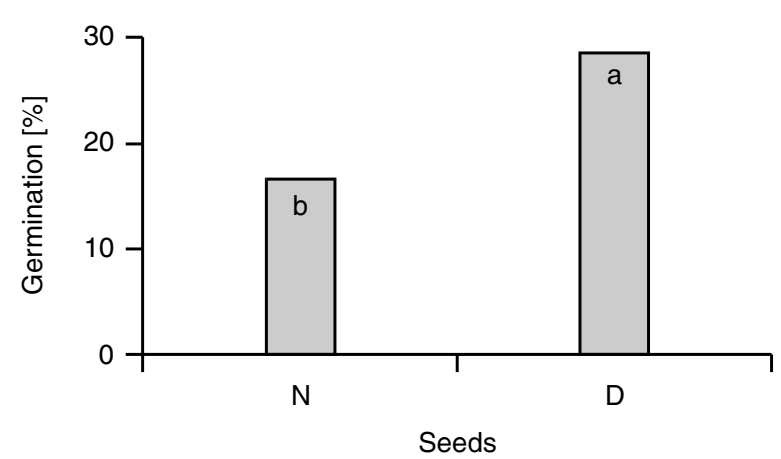

Fig. 7. The effect of initial moisture contents of nuts $(\mathrm{N}-$ not dried after collection; D - dried after collection) on seed germinability. Results denoted with identical letters do not differ at $\mathrm{P}=0.05$ (Tukey's T-test). a significantly lower germination level than the other thermal systems. Initial moisture content of seeds had a strong effect on seed germination - a significantly lower percentage of seeds, which were not dried after collection, germinated in comparison to dried seeds (Fig. 7).

\section{Experiment 2}

The highest percentage (54\%) of seeds germinated at the temperature of $3 \sim 15^{\circ} \mathrm{C}$, when a 2 -week warm stratification phase was applied, after which seeds were dried and scarified, and after scarification they were stratified at $3^{\circ} \mathrm{C}$ for 14 weeks (Fig. 8). It also results that as many as 11 other results (out of 18) did not differ from the highest value at $\mathrm{P}=0.05$.

It results from the conducted analysis of variance that neither the length of the warm phase of stratification nor the temperature of the germination test were factors significantly affecting seed germinability. Such an effect was found only for drying and scarification of nuts. After drying and scarification seeds germinated at a significantly higher percentage than after only drying. In turn, dried seeds germinated at a significantly higher percentage than non-dried seeds (Fig. 9).

\section{Experiment 3}

During stratification at $3^{\circ} \mathrm{C}$ the first germinating seeds appeared after approx. 15 weeks.

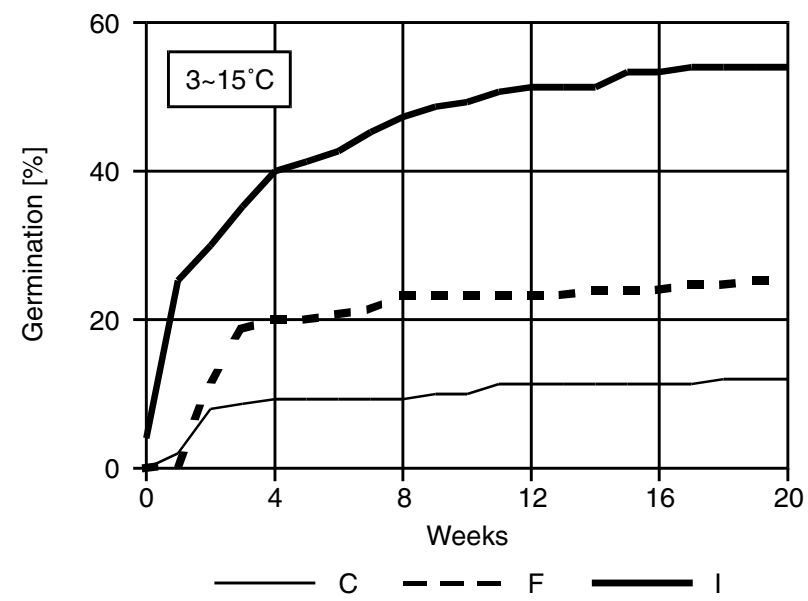

Fig. 8. Course of seed germination at cyclically alternating temperature of $3 \sim 15^{\circ} \mathrm{C}$, after stratification at $15 \sim 25^{\circ} \mathrm{C} / 3^{\circ} \mathrm{C}$, with a 2 -week warm phase with cyclically variable temperature changed every $24 \mathrm{~h}$, and a cold phase of 17 weeks (C), 16 weeks (F) and 14 weeks (I). In variant F after a warm phase of stratification seeds were dried for 3 days at room temperature, followed by continued stratification at $3^{\circ} \mathrm{C}$, while in variant I after drying seeds were additionally mechanically scarified - see Figure 2 .

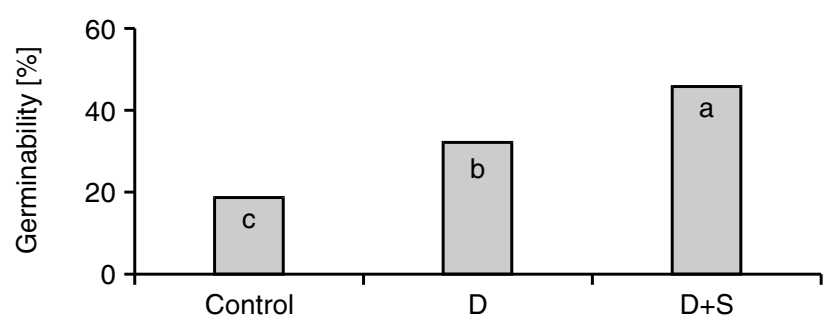

Fig. 9. A comparison of seed germination depending on applied procedure: drying of nuts (D), drying and scarification $(D+S)$ or none of these (Control), after warm phase of stratification at $15 \sim 25^{\circ} / 3^{\circ} \mathrm{C}$. The results were tested by Tukey's T-test at $\mathrm{P}=0.05$. 

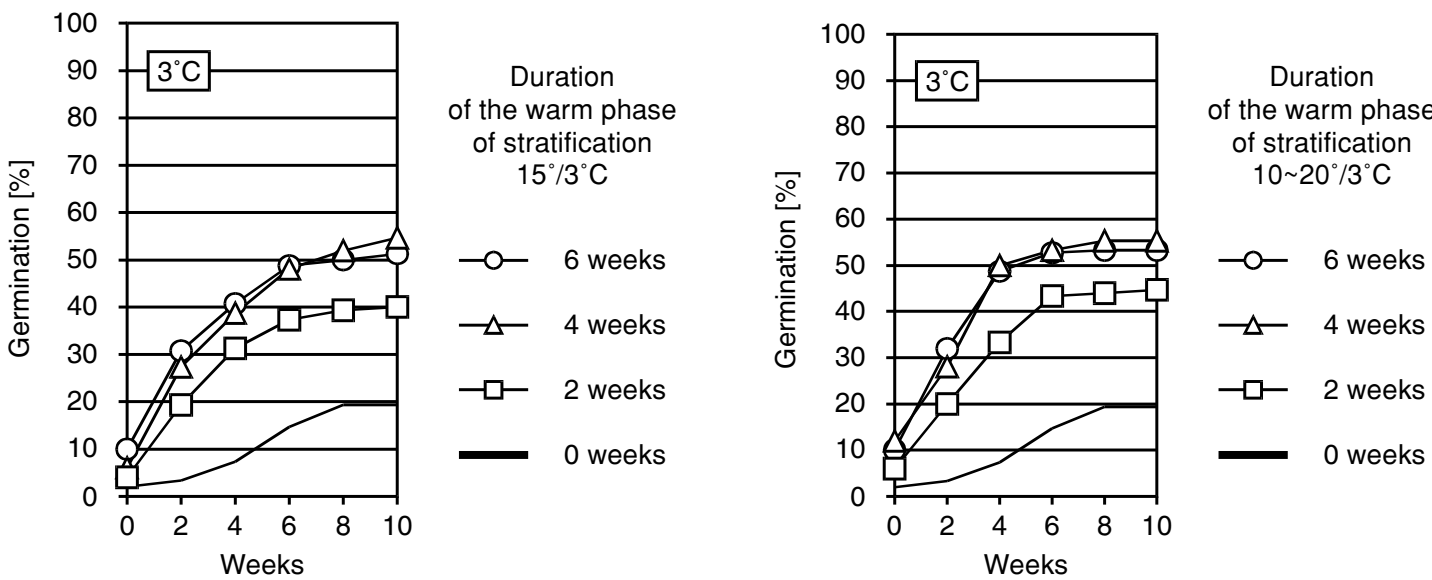

Fig. 10. Course of seed germination at $3^{\circ} \mathrm{C}$ after warm-followed-by-cold stratification at $15 / 3^{\circ} \mathrm{C}$ or $10 \sim 20^{\circ} / 3^{\circ} \mathrm{C}$, with the warm phase of $0,2,4$ or 6 weeks and a cold phase of 15 weeks. After the warm phase of stratification seeds were dried at room temperature to moisture content of approx. $10 \%$.

Seeds not subjected to warm stratification (control) germinated only at $20 \%$ after 18 weeks of stratification at $3{ }^{\circ} \mathrm{C}$.

When a 2-week warm phase was applied (irrespective of the temperature: $15^{\circ} \mathrm{C}$ or $10 \sim 20^{\circ} \mathrm{C}$ ) seed germinability at $3^{\circ} \mathrm{C}$ increased to over $40 \%$, while after the extension of this phase to 4 and 6 weeks - to over $50 \%$ (Fig. 10).

It turned out as a result of the conducted analysis of variance that only the length of the warm stratification phase had a highly significant effect on seed germinability, and not the thermal layout of this phase at a constant temperature of $15^{\circ} \mathrm{C}$ or at a cyclically variable temperature of $10 \sim 20^{\circ} \mathrm{C}$.

After the results were tested using Tukey's test (Fig. 11) statistically the lowest results were obtained after stratification only at $3^{\circ} \mathrm{C}$, slightly better after the application of a 2week warm phase, and the highest after the application of a 4- or 6-week warm phase preceding the cold phase at $3^{\circ} \mathrm{C}$.

\section{Experiment 4}

Drying performed once or twice during the warm phase of stratification at $15^{\circ} / 3^{\circ} \mathrm{C}$, and next their scarification resulted in the highest percentage of seed germination $(73.5$ and $74.8 \%$, respectively). However, from the statistical point of view these results did not differ significantly from germinability of seeds subjected only to drying and not subjected to mechanical scarification (Fig. 12). It also results from the experiment that drying nuts 3 times had an adverse effect on later seed germination (a significant decrease in germination to $48.5 \%$, Fig. 12).

In spite of the lack of difference in seed germinability between dried nuts and dried and scarified nuts during the

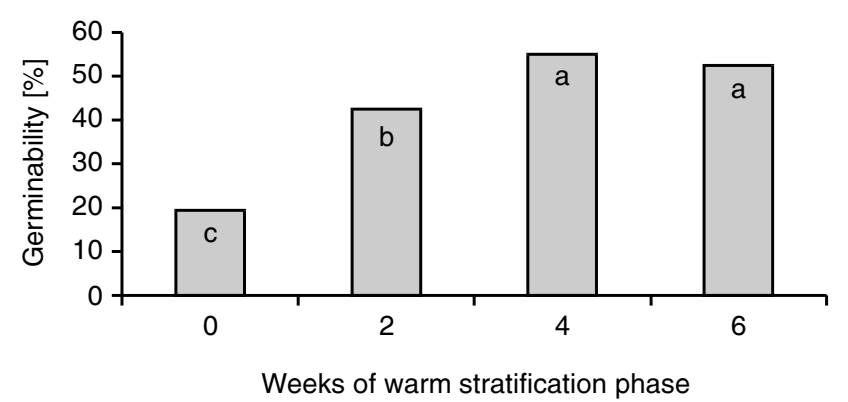

Fig. 11. The effect of length of warm phase of warm-followed-by-cold stratification on seed germinability. Results denoted with identical letters do not differ significantly at $\mathrm{P}=0.05$ (Tukey's T-test).

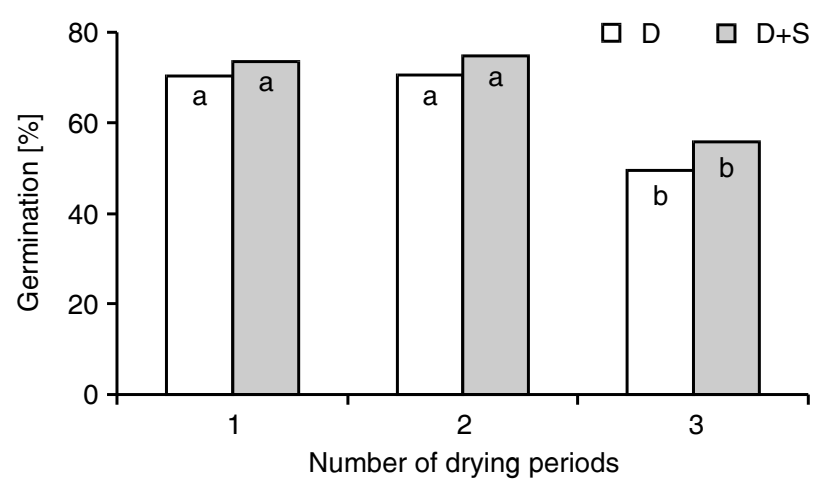

Fig. 12. A comparison of seed germinability after warm-followed-by-cold stratification at $15^{\circ} / 3^{\circ} \mathrm{C}$, with a 9-week warm phase during which nuts were dried (D) 1, 2 or 3 times or after the last drying seeds were additionally scarified $(\mathrm{D}+\mathrm{S})$. Results were tested using Tukey's T-test at $\mathrm{P}=0.05$.

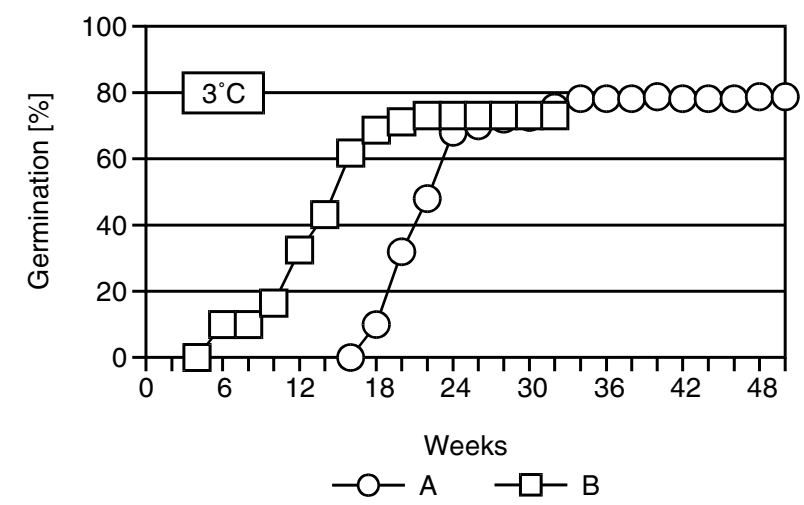

Fig. 13. The course of seed germination at $3^{\circ} \mathrm{C}$. Cold stratification was preceded by a 9 -week warm phase at $15^{\circ} \mathrm{C}$. A - nuts dried; B - nuts dried and scarified. Denotations as in Figure 4.

warm phase of stratification there was a distinct difference between the course of their germination (Fig. 13). Seeds from dried nuts, whose coat was mechanically scarified, during the warm phase of stratification started to germinate as early as after 5 weeks of stratification at $3^{\circ} \mathrm{C}$, and the course of their germination lasted as long as to approx. the 20th week. In contrast, seeds from nuts subjected only to drying during the warm phase of stratification started to germinate after 16 weeks of stratification at $3{ }^{\circ} \mathrm{C}$, and the level of their germination settled around the 34th week 
(Fig. 13). Therefore scarification of nuts resulted in shortening the time of seed stratification by ca. 14 weeks.

\section{DISCUSSION}

Literature data on the conditions of seed dormancy release and germination in bladder nut are exceptionally scarce and contradictory. Bärtels (1982) was of the opinion that in order to complete the development of the embryo seeds require a long-term stratification of as many as 18 months. In turn, Nikolaeva et al. (1985) stated only (after Misnik 1949) that seeds require long-term cold stratification. Piotto and Di Noi (2001 and 2003) were of a different opinion, recommending sowing of seeds soon after collection or in the spring after a 24-week stratification (first a 12-week warm stratification followed by a 12-week cold stratification), with no details on the range of thermal conditions. Under natural conditions bladder nut propagated from seeds is found in sites of higher accumulation of humus (Cieciński 2004).

Our experiments on seed germination showed that fully ripe nuts, not dried after collection (with MC of over 30\%), require for dormancy release a long-term warm-followed-bycold stratification with at least a 12 -week warm phase and a cold phase of over 20 weeks at $3^{\circ} \mathrm{C}$. A shorter, i.e. 8-week warm phase of stratification resulted in a significant decrease in seed germinability. Cyclically alternating $\left(20 \sim 25^{\circ} \mathrm{C}\right)$ temperature of the warm phase in the cycle of $24+24 \mathrm{~h} /$ day resulted in a significant increase in seed germinability in comparison to the temperature of $15 \sim 25^{\circ} \mathrm{C}$ (Fig. 5). However, a significant effect on seed germination rate was found to the highest degree for drying of nuts after collection to MC of $11.3 \%$ before stratification (Fig. 7).

In case of another seed lot (from 2001) it was shown that the duration of the warm phase of stratification at $15 \sim 25^{\circ} \mathrm{C}$, from 2 to 6 weeks, had no statistical effect on seed germinability (Fig. 2). However, as can be seen for seeds from experiment 3 (Fig. 11) the lack or the application of a too short, only 2-week, warm stratification preceding stratification at $3^{\circ} \mathrm{C}$ had a significant effect on the lowering of seed germinability in comparison to the application of warm phase of 4-6 weeks.

After the initiation of seed germination during the cold phase of stratification at $3^{\circ} \mathrm{C}$, the application of cyclically variable temperature at $3 \sim 15^{\circ} \mathrm{C}(16+8 \mathrm{~h} /$ day $)$ had no effect on the level of their germinability when compared with the cold phase at $3^{\circ} \mathrm{C}$ (Fig. 2). Seeds germinated equally well at both temperatures

In turn, a significant effect on seed germination was found for a 3-day drying of nuts at room temperature and their scarification after the completion of the warm phase. Both these procedures contributed to the highest degree to seed germination. Dried seeds from nuts not subjected to scarification germinated at a statistically lower rate than those from dried and scarified nuts, but to a higher degree than seeds from non-treated nuts (Fig. 9).

In case of seeds collected at the Arboretum in Bolestraszyce no significant difference was shown in seed germinability between nuts dried (once or twice) and nuts dried and additionally mechanically scarified. Scarification of nuts has fastened seed germination considerably. In turn, seeds from nuts subjected to drying repeated three times during a warm phase of warm-followed-by-cold stratification sho- wed a significantly lower germination rate. It can be seen from the above that not every bladder nut seed lot positively responds to applied scarification of nut coats by increased seed germinability.

It needs to be stressed that nut scarification should be conducted solely when they are dried to moisture content of $10-14 \%$. Scarification of moist nuts contributes to damage of the outer layers of cotyledon cells, which in half from the side of the embryo axe adhere to the outer coat layers and are almost connected. Soon during stratification, the damaged cells will be sites where seed decay will initiate.

Seeds with a short radicle $(1-3 \mathrm{~mm})$ may be sown to the soil in the spring.

\section{ACKNOWLEDGEMENTS}

I wish to express my sincere thanks to the district forest manager of the Dukla Forest District, Z. Władyka, M.Sc, Eng., and Prof. J. Piórecki, Director of the Arboretum in Bolestraszyce for their kind help in obtaining seeds of European bladder nut for the purpose of this study.

\section{LITERATURE CITED}

ANONYMOUS 2001. The official Gazette „Dziennik Ustaw No. 106, item 1176 of 29 September 2001 (in Polish).

BÄRTELS A. 1982. Rozmnażanie drzew i krzewów ozdobnych [Propagation of ornamental trees and shrubs]. PWRiL, Warszawa. pp. 436 (in Polish).

BERANOVÁ L., BENEDIKOVÁ M. 2005. Morfologická variabilita plodů a semen dřinu obecného (Cornus mas L.) a klokoče zpeřeného (Staphylea pinnata L.). [Fruits and seeds morphological variability of Cornus mas L. and Staphylea pinnata L.]. Zprávy Lesnického Výzkumu 2: 90-101. (in Czech).

BROWICZ K. 1959. O rozmnażaniu się kłokoczki południowej (Staphylea pinnata L.). [On the propagation of the bladder nut (Staphylea pinnata L.]. Rocznik Dendrolog. XIII: 125-130 (in Polish).

CIECIŃSKI J. 2004. Krzew naszych przodków [A shrub of our ancestors]. Aura - ochrona środowiska 3: 34-35 (in Polish).

GORDON A.G., ROWE D.C. 1982. Seed Manual for ornamental trees and shrubs. Forestry Commission, Bulletin No. 59.

GOSTYŃSKA M. 1961. Rozmieszczenie i ekologia kłokoczki południowej (Staphylea pinnata L.) w Polsce [The Distribution and Ecology of the Bladder nut - (Staphylea pinnata L.) in Poland]. Arboretum Kórnickie VI: 5-71 (in Polish).

LATAŁOWA M. 1994. The archeobotanical record of Staphylea pinnata L. from the $3^{\text {rd }} / 4^{\text {th }}$ century A.D. in northern Poland. Vegetation History and Archeobotany, 3 (2): 121-125.

MISNIK G.E. 1949. Proizvodstvennaja charakteristika semjan derev'ev i kustarnikov gorodskich nasaždenij. Moskva, Leningrad. pp. 207. (in Russian)

NIKOLAEVA M.G., RAZUMOVA M.V., GLADKOVA V.N. 1985. Spravočnik po proraščivaniju pokojaščichsja semjan. Izd. Nauka, Leningrad. (in Russian).

PIOTTO B., DI NOI A. (ed.). 2001. Propagazione per seme di alberi e arbusti della flora Mediterranea [Seed propagation of Mediterranean trees and shrubs]. ANPA, Roma. pp. 212. (in Italian).

PIOTTO B., DI NOI A. (ed.). 2003. Seed propagation of Mediterranean trees and shrubs. APAT 16/2003. pp. 108.

SUSZKA B., MULLER C., BONNET-MASIMBERT M. 1996. Seeds of forest broadleaves from harvest to sowing. INRA, Paris. pp. 295.

ŚRODON A. 1992. Kłopoty z kłokoczką [Troubles with Staphylea pinnata L.]. Wiad. Bot., 36 (1/2): 63-67 (in Polish) 